\title{
THE REFERENCE OF “GOD” REVISITED
}

\author{
Hugh Burling
}

\begin{abstract}
I argue that the reference for "God" is determined by the definite description "the being that is worthy of our worship." I describe two desiderata for rival theories of the reference of "God" to meet: accessibility and scope. I explain the deficiencies of a view where God is dubbed "God" and the name passed down by causal chains and a view where "God" picks out the unique satisfier of a traditional definite description. After articulating the "Worship-Worthiness" view, I show how it best satisfies the desiderata. I then respond to some putative counterexamples to the view.
\end{abstract}

\section{Introduction}

What should our semantic theory for the term "God" be? How is it that when we use the term "God" referentially, it really picks out God? Alternatively, what is picked out by "God"? Any answer to either of these questions will help answer the other. The answer I defend below is that the reference of "God" is determined via the implicit sense of the term, the definite description "the being that is worthy of our worship." I think that this view leads inexorably in the direction of perfect being theism, but showing this goes beyond the scope of the argument here. To understand what is at stake in these two questions about how "God" refers and who "God" refers to, I begin by describing two focal desiderata for a semantics for "God": what I call "accessibility" and "scope." Both accessibility and scope catch various reasons given in favour of one theory against another and can be satisfied to greater and lesser degrees by different theories. Accessibility concerns how easy it is for individual "God"-users to meet the conditions on successful reference imposed by the theory. Scope concerns how much disagreement about the nature of "God"'s referent can be tolerated and how far our theory "draws together" parties to disagreements in co-reference rather than letting them "split apart" easily.

I examine three competing theories in contemporary philosophy of religion to see how they fare in meeting our desiderata. The first, which I will call the "Causal Reference" view (CR), has explicit defenders in both 
William Alston ${ }^{1}$ and Meghan Sullivan. ${ }^{2}$ In short, CR tells us that "God" is a proper name bestowed by Abraham on the object of his religious experiences $^{3}$ and taught to his astronomically numerous descendants through a chain of testifiers. The second, which I will call the "Descriptive Denotation" view (DD), is defended in hybrid form by Richard Gale, ${ }^{4}$ but is a good umbrella for "traditional" views given theologians' habit of defining "God" in terms of a list of attributes that set Him apart from creatures. DD tells us that "God" picks out an object which uniquely satisfies a definite description, perhaps consisting in a precise list of predicates, or perhaps a cluster of them. The third view is candidate for a specific "traditional" view which I will call the "Worship-Worthiness" view (WW). The Worship-Worthiness view gives God's worthiness of worship a more fundamental role than merely being an example of one of the properties DD requires, telling us instead that "God" refers simply to "the being that is worthy of our worship."

For each view, I will articulate it and assess how far it satisfies the two desiderata. Ultimately, I conclude that the Worship-Worthiness view fares the best: it makes God more easily semantically accessible and supports the widest scope for co-reference between those who use the term "God." It's worth emphasizing, however, that this is a comparative argument: $C R$ and DD are not "defeated," with WW the "survivor." Accessibility and Scope are not "fail-or-pass" necessary conditions for a successful theory of the reference of "God," but rather desiderata which a theory can meet more or less successfully. Worship-Worthiness, I argue, meets them with more success than its rival, $\mathrm{CR}$, and its less precise parent, DD.

Before proceeding, a significant qualification needs to be made to everything that follows. I tie up the accuracy of a semantic theory for "God" with how far it meets the Accessibility and Scope desiderata. Both desiderata crucially involve successful reference, albeit in different ways, by "God" to-something; what this something must be, is part of what the rival theories disagree about. But successful reference usually requires that the referent actually exist. This means that the accuracy of each theory is in turn going to depend to some extent on some extremely controversial matters of fact about metaphysics: for example, whether Abraham's or some other prophets' religious experiences really had independent objects as causes, or whether there is a being satisfying whatever list DD stipulates, or whether there is in fact a being worthy of worship..$^{5}$ Given the significance of the disagreements between the rival theories about what

\footnotetext{
${ }^{1}$ Alston, "Referring to God."

2Sullivan, "Semantics for Blasphemy."

${ }^{3}$ This is an iteration of CR for "God" as used in the mouths of Abrahamic monotheists speaking English. Zoroastrians, for example, might translate "Ohrmazd" as "God" and thereby inherit "God" from Zarathustra's initial ostension.
}

${ }^{4}$ Gale, On the Nature and Existence of God.

${ }^{5} \mathrm{My}$ thanks to an anonymous reviewer for raising this issue. 
"God" might turn out to refer or fail to refer to, and not just about how successful reference comes about, it won't be enough to simply stipulate that we are evaluating the rivals having taken something called "theism" for granted. The theories have implications for what the "proper" content of "theism" is. Instead, we can drive a wedge between those matters of metaphysical fact (whether a deity spoke to Abraham, whether there is an eternal creator or perfect being, and so on) and the relative success of the theories by considering how semantically accessible each makes their referent for "God," and the Scope for co-reference they produce between users of "God," another way. We should evaluate each theory in conditional terms: if the referent of God the theory suggests "God" refers to did exist, how semantically accessible would that being be for "God"-users? And how much co-reference between doxastically divergent "God"-users would there be? This way the ability to meet either of the desiderata is unhitched from those metaphysical controversies which lie outside the linguistic, phenomenological, and axiological considerations directly in play.

\section{Accessibility}

We find out what a word means by looking at how it works. Trivially, we do things with words by using them within what I'll call "linguistic practices." In natural languages, the rules governing these practices are implicit and often fuzzy or very complicated. Moreover, in natural languages, some terms and expressions can operate very differently in different contexts, so that it is helpful to think of those terms as being employed in a wider web of interlocking linguistic practices. For example: we are not primarily interested here in what we refer to, if anything, when we shout the term "God" when we get hurt; that is, while using the profanity practice; ${ }^{6}$ but instead we are interested in what the term refers to when we use it to discuss what God is like, to talk to Him, and to accomplish other goals and moves in the theistic religious linguistic practice. Note well that we use this practice not only to find out or teach others about God but, also, to attempt to draw ourselves closer to Him and carry out any duties we have toward Him which require language use. Given that peoples' typical use of language is a universally available source of data about how words "work," and that other sources such as metaphysical or axiological commitments are likely to be more controversial, I suggest that we analyze linguistic practices by adopting a charitable hermeneutic. This means taking practitioners' expressions at face value except in cases where we have strong reasons to suppose some literary or rhetorical trope is at work. It likewise means taking intended or purported reference to be evidence, if defeasible, of actual reference. Given that natural languages both develop over time and between places, but are rule-governed enough

\footnotetext{
${ }^{6}$ Sullivan ("Semantics for Blasphemy") argues that blasphemy is uniquely wrong precisely because blasphemous uses confuse us about the rules of the theistic religious linguistic practice. She is not interested in blasphemy in this sense, however but in the sense of libelling God (160).
} 
to merit analysis, I would finally suggest that whether or not a "rule" obtains within a practice does not depend on whether the words involved in the practice are always used in exactly the way that rule implies. Nor, I suggest, does a rule's obtaining depend on unanimous agreement with that rule, among practitioners, were it described back to them. Indeed, if it did, the existence of philosophical disagreement about the semantics for "God" would mean that there could be no such semantics.

One easily discernible feature of the theistic religious practice is that most humans seem capable of playing it successfully. It doesn't seem to require "special training." Although we might use it better if we have certain kinds of training, children seem to be able to speak as intelligibly about and to God as they can about and to creatures. So, we can infer that God is highly linguistically accessible via the term "God." What this evidence suggests is that, in general, successful reference to or denotation of God by "God" is easy to achieve. So, I contend that our linguistic habits indicate that the object, God, is highly, or very easily, accessible by the term "God." For brevity I will also write as if accessibility pertains to the term, "God," by which I only mean that it is easy for us to access God by using it. We are judging accounts as to whether they render "God" more or less accessible, and they do better where they make it more so.

A denier of the claim that "God" is very accessible might reject the above inference from the ability of children and the theologically untrained to properly use "God." They might block the inference by claiming that ignorant or apparently untrained speakers have typically been raised in a religious tradition or in a culture with a theological hinterland; and this "catechesis," or intellectual hinterland, will constitute a form of "special training."

But consider those we have in mind under the class of "apparently untrained speakers": not only small children in active religious communities but, also, those in post-religious societies. While a non-religious adult in such a society might have come across art and literature with religious themes, their children will not have intellectual access to the cultural hinterland which our objector appeals to as a form of special training. And the level of conceptual content in the "catechesis" enjoyed by a very young, but apparently competent "God"-user, will be very thin indeed. So, either the sense of "special training" is so thin that it is compatible with a very great deal of accessibility, and we arrive at the conclusion that "God" is highly accessible; or, the original inference goes through.

One specific demand this ease of access makes, evident from the above cases of ignorant or juvenile speakers, is that one can successfully refer to God by using "God," without needing a sophisticated conceptual apparatus related to one's use or understanding of the term. According to this demand, a semantic theory for "God" will do better insofar as the conceptual resources demanded of its users are low enough to match many typical cases, such as the child at prayer or the questions of the spiritual seeker in a post-religious society. If such people are to use "God" successfully, 
then such usage cannot require much by way of beliefs about God or understanding of the senses of predicates involved in such beliefs.

I don't intend to settle the question of just precisely how linguistically accessible the theistic linguistic practice makes God-nor do I appeal to a precise value in my arguments below. Since below we are comparing three theories for accessibility, I hope that our familiarity with religious practices will indicate to us that the Causal Reference and Descriptive Denotation views do not account for sufficient accessibility and that Worship-Worthiness does not make God "too" accessible. Dialectically, however, the accessibility criterion is on safe ground, since Alston, Sullivan, and Gale use concerns about conceptual demands ${ }^{7}$ and fragile causal chains ${ }^{8}$ to motivate their preferred views.

\section{Scope}

Users of the theistic religious linguistic practice should be able to corefer to God when they use the same term as each other-even when they strongly disagree about what the thing each calls "God" is like. Our different theories provide for co-reference in different ways; and those differences mean that each theory implies a different scope for co-reference.

While I find it intuitive that our theory of how "God" refers will be preferable the wider the scope for co-reference it establishes, a correct theory must draw the line somewhere. We only need to find one case where it is uncontroversial that two speakers uttering "God" in their language do not co-refer to show that such a line exists. Yet there are two aspects of the theistic religious linguistic practice which I think indicate that the right theory will extend co-reference very widely.

The first is the explicit language used in much religious and theological controversy. When Christians, Jews, Muslims and (many) Hindus disagree, they appear to disagree about the nature of the same object. Christians insist that God was incarnate in Christ, but Jews insist that God has not been (and perhaps never will be) incarnate; Muslims claim that God is only one "person," some Christians that He is three, and some Hindus that It is none. These are the sorts of claims which cut to the heart of theology. Disagreements typically take the form of "I believe that $a$ is F, but you believe $a$ is G" or "We should $\phi a$, not $\psi$ a." There is no inevitability to this, and it is what we would expect if co-reference is occurring. If co-reference were not the norm, we would expect a lot more disagreement to be couched differently. We would expect disagreements to typically take the form of "I believe there's an $x$ which is $\mathrm{F}$, $a$, but no $x$ which is $\mathrm{G}$, but you believe there's an $x$ which is $\mathrm{G}, b$," or "We should $\phi a$ rather than $\psi b$." We can regard the assumption of co-reference as an explanation for why theological and religious disagreement tends to take the first two forms, rather than the latter two. If co-reference were not in place, then disagreements of the

7See Alston, "Referring to God," 116 and Sullivan, "Semantics for Blasphemy," 161-163.

${ }^{8}$ Gale, On the Nature and Existence of God, 301. 
first two forms would not typically be genuine disagreements, but rather, the reference for "God" in the parties' mouths would be "split"; and those parties would routinely labour under a misunderstanding, talking past each other. ${ }^{9}$ Perhaps there is an alternative explanation which is consistent with widespread "split reference" between "God"-users, but it seems to me that our motivation to look for such an explanation will be provided by evidence in favour of a view with low scope. A charitable, face-value reading of the language typical in religious and theological controversy puts the presumption in favour of high scope. ${ }^{10}$

The second arises from the translatability of "God" across languages. ${ }^{11}$ Missionaries seem able to make theistic claims understood across very different cultures, often without shared linguistic histories. It is natural to suppose that such translation was easy due to shared reference by the two poles of the translation. If "God" (and its translations) refer to One Thing, and our minds are equipped to distinguish between that One Thing and other things, translation will be easy. If this explanation is right, the history of proselytism will provide evidence of very widespread co-reference.

Terms are sometimes (apparently) translated without co-reference. For example, a referent can be dubbed with a term in one language, and its features over time create a sense for that term; then a different referent, known to the speakers of a second language, can share enough of those features that the term is translated into whatever term in the second language refers to the other referent. Over time, commerce between speakers of the two languages can come to clarify resulting confusions. Cases like this abound in the taxonomy of wildlife. Should we think that the translation of "God" is such a case? On the one hand, even if (for example) El-Shaddai and Chukwu were in fact two distinct individuals, despite Christian missionaries to Nigeria translating both as "God," it would be much harder for us to establish that they are two distinct individuals than it is for biologists to establish the distinct speciation of two geographically separated populations in the same genus so that the "confusion" could be "cleared up." On the other, when we reflect on the translation process, and the "clarification" process, we immediately begin to imagine instances of the theological controversies discussed above. Missionaries working in the cases we are considering tried to persuade the Igbo people that they

\footnotetext{
${ }^{9}$ Versions of this argument for co-reference between Christians and Muslims have been offered by Dale Tuggy in his "The 'Same God' Controversy and Christian CommitmentPart 1," and by Sullivan ("Semantics for Blasphemy," 163).

${ }^{10}$ See Bogardus and Urban's "How to Tell Whether Christians and Muslims Worship the Same God" (179-181) for an explanation of why these habits of disagreement do not guarantee co-reference between "God"-users in different traditions: it is possible that these practices obtain and yet co-reference is broken by reference shift. My argument here is that co-reference is a charitable "null hypothesis" which explains these features of theological disagreement and which we need good reasons to reject.

${ }^{11}$ An early version of the argument that the translatability of "God" between languages indicates co-reference between religious traditions can be found in Geach, God and the Soul (108-109).
} 
were mistaken about details concerning Chukwu's activities and nature, not Its existence as opposed to El-Shaddai's - if they had taken the latter strategy, "Chukwu" would not now translate "God" in Igbo translations of the Bible. I take it to be the null hypothesis, or at least more charitable, to suppose that missionaries and converts at the time could discern the common reference of different terms, rather than that they were "misled" by similarities between two different (postulated) beings. ${ }^{12}$

Alternatively, there is the possibility that instead of co-reference across languages, there has occurred reference change over generations of contact between dominant monotheistic, and dominated heno-, panen-, or polytheistic cultures. In the Chukwu case, then: the term comes to refer to the same thing as "God" as converts outnumber traditionalists among the Igbo people. Again, however, I think that an interpretation of the history of "God" which is charitable to its users shows this possibility to be just that; the actual use of the word indicates co-reference.

Assuming co-reference between the missionary and convert, such linguistic-historical evidence also tells in favour of both kinds of accessibility, since any necessary concepts must be coarse-grained enough to be available from within unconnected intellectual histories.

Finally, inclusivist accounts of theological knowledge, or pluralistic philosophies of religion, according to which all or most "religions" are "really about" the "same thing," such as John Hick's, ${ }^{13}$ depend on a very extensive co-reference for "God" between speakers with very different arrays of theological beliefs and concepts. This means that theories of the reference of "God" which support wider co-reference will benefit from the support of arguments for pluralism or inclusivism, be these arguments moral, prudential, phenomenological, or epistemic. ${ }^{14}$

The above two arguments together make a generous scope for coreference a desideratum of theories of how "God" refers.

\footnotetext{
${ }^{12}$ This is the interpretation of the interaction between the Ibo and Christian missionaries described by Edmund Egbo in his "A Reassessment of the Concept of Ibo Traditional Religion" (75-79). I emphasise that this interpretation is charitable with respect to the motivations of missionaries, their local collaborators, and conversions being intellectual or theological-as one anonymous reviewer has pointed out, developments in translations between religious linguistic practices can be driven by pragmatic considerations as well as the desire to "get it right." If we assume, however, that these translation practices are routinely "infected" by considerations that would lead their development to tend away from a coherent semantics or successful reference, then we should expect there to be no successful semantic theory for a term with as broad a history as "God" - only a series of case-by-case explanations of use.

${ }^{13} \mathrm{An}$ influential example of a pluralism which guarantees that all religions are about the same thing is John Hick's. Unfortunately, Hick's account risks rendering all religions being about something which might lead many "God"-users to cease worshipping it: a Kantian noumenon he calls "the Real" (An Interpretation of Religion, 241-249).

${ }^{14}$ I thank an anonymous reviewer for pointing out that particular versions of pluralism or inclusivism might include or generate claims of co-reference between different uses of "God" which many readers would find highly contentious-Hick's in particular. But this need not deprive the scope criterion of the support it receives from any arguments for these views, wherever the arguments do not themselves entail contentiously wide scope.
} 
Since the arguments for greater accessibility and wider scope involve empirical generalizations about religious and theological practice, they do not support precise delineations as to how much "split reference" a theory can allow or produce, nor how semantically vulnerable it can make or allow "God" to be, before it becomes unacceptable. Nor do they give clear instructions for how to weigh these desiderata against each other and against other considerations. In considering the three competing views below, therefore, they will help us to organize our judgments and see connections in the current debate, but will not straightforwardly deliver deductive judgment of victory.

\section{The Causal Reference View}

The Causal Reference (CR) view applies the theory of the reference of names and natural-kind-terms developed in the 1960s and 1970s, and associated with Saul Kripke, ${ }^{15}$ to the divine case, taking "God" to be a proper name. According to this "causal theory," generally speaking, who (or what) a name or natural-kind-term refers to depends on who was "baptized" with it when the initial users of that name began to use it. Those initial users then communicate it to subsequent users, who defer to the initial users regarding its reference. The second generation can be deferred to by the third, and so on, until members of enormous communities spread diachronically across time can use the term to successfully refer to the initial individual, even if they could never have met that individual, and even if they have few true beliefs about the individual. In the case of "God," Alston suggests that religious communities might have ways of identifying a common Object of their "religious" experiences and "baptizing" it "God"; the handing down of their religious practices enables the communication of the name to subsequent generations. ${ }^{16}$

CR initially scores well on accessibility because virtually no conceptual apparatus is required on the part of "God"-users to successfully refer to God using "God." As Sullivan explains,

Speakers do not need a unique description of God, nor do they even need an accurate description of God in order to use a divine name to refer to him. Children and anyone else who finds themselves theologically impoverished can refer merely by deferring to others who are in a position to refer. ${ }^{17}$

Unfortunately, Sullivan argues that the linguistic accessibility of God is reduced by the potential changing of the reference of "God" over time. According to causal theories of reference, irregularities in the causal chain between baptism and late speaker can make it the case that the late speaker fails to refer to the baptized object. Speakers within the community might

\footnotetext{
${ }^{15}$ The locus classicus is Kripke's Naming and Necessity.

${ }^{16}$ Compare the versions of this account given by Alston ("Referring to God," 118-119) and Sullivan ("Semantics for Blasphemy," 162, and "The Semantic Problem of Divine Hiddenness").

${ }^{17}$ Sullivan, "The Semantic Problem of Divine Hiddenness," 43.
} 
use the already-taken name to baptize a new object, and so introduce a "competing chain": ${ }^{18}$ if later speakers defer to the re-users of the name, they will refer to the new object rather than the old. Things can be more complicated: Sullivan gives the case of King Arthur ${ }^{19}$ to illustrate how late inheritors of a name could, on the causal view, refer indiscriminately to any member of a collection of objects. Whilst there might have been an original baptizand of "Arthur" - let's say, a retired Roman general gone native after too many feasts at Tintagel - a whole band of fictional or obscured heroes hailed in proto-Arthurian epics bear just as strong causal relations to the name in our mouths.

Suppose that we, like Alston, take "God" to refer to the common religious-experiential object of the ancient Israelites..$^{20}$ Sullivan argues that, empirically, that puts "God" users in semantic hot water: "the contemporary Catholic Church is the product of two thousand years of theological mergers and acquisitions ... early Church history is full of events where distinct cultures puzzled over how to combine their metaphysical theories with the growing church. . . . And Catholics are not alone in this; nearly every major religion can find syncretistic events in their formative years." ${ }^{21}$ On $\mathrm{CR}$, then, there is a substantial risk that modern-day users of "God" lie at the ends of diverse, confluent, or interrupted causal chains so that many do not successfully refer to God, and hence refer to different beings or refer with varying degrees of success. Sullivan reckons that this risk raises a "problem of semantic divine hiddenness" because many believers might not have linguistic access to God of the sort we would expect personal relationships to require. So, CR puts both God's semantic accessibility, and the co-reference of "God," in jeopardy to intellectual history. For this reason we should judge the theory to fare poorly with respect to our two desiderata.

To shore up the theory, we can offer solutions to the "semantic hiddenness" Sullivan identifies. Her preferred response is to add a theological epicycle to the Causal Reference view, where divine providence secures the causal chain in the required way, through the Holy Spirit's work in the Church. She prefers this to a potential response coming from Alston's original defence of $C R$, which she regards as inadequate because it would restrict the scope of the theory so much that co-reference between theists of different Abrahamic traditions would be threatened. ${ }^{22}$ It's worth considering Alston's alternative, however, since it not only protects CR from rendering "God" too semantically vulnerable, and thereby God too inaccessible, but also protects CR from a central objection of Gale's.

\footnotetext{
${ }^{18}$ Sullivan, "The Semantic Problem of Divine Hiddenness," 44.

${ }^{19}$ Sullivan, "The Semantic Problem of Divine Hiddenness," 44-45.

${ }^{20}$ As he does in Alston, "Referring to God," 121.

${ }^{21}$ Sullivan, "The Semantic Problem of Divine Hiddenness," 46.

${ }^{22}$ Sullivan, "The Semantic Problem of Divine Hiddenness," 48-49.
} 
Gale argues ${ }^{23}$ that it is impossible for subjects of theistic religious experiences to identify that they are seeing the same object as in their last experience, and hence as in each other's, because picking out and re-identifying individual phenomenal objects requires a zone of at least two dimensions in the putative perceptual field. This would make it impossible to satisfy the requirement of CR that God be baptized by ostension to begin causal chains of reference. Alston insists that "we should not suppose that we can identify a priori any limits on what objective features can manifest themselves in patterns of phenomenal qualia ... we can learn only from experience what features and activities of God can be recognizable by the way God presents Himself." ${ }^{24}$ Nevertheless, defenders of the possibility of identifying God in religious experiences need to have some rules by which their subjects would tell the difference between an appearance of God and an appearance of something else, or no appearance at all. Alston's solution is to lean on the practices of the communities in which the experiences occur. What he calls "mystical doxastic practices" are sets of rules, habits, and attitudes which allow their practitioners to discern when God is appearing to them. ${ }^{25}$ So Abraham and his heirs and successors can successfully pick out God and dub Him "God" by using their mystical doxastic practice (however rudimentary theirs was). They can pass on the name for reference by deference to their intention, as well as teaching their successors how to re-locate God experientially so that "if things go right, we also attain some firsthand experiential acquaintance with God to provide still another start for chains of transmission." ${ }^{26}$

But the doxastic practice set-up also provides for a solution to Sullivan's semantic problem of divine hiddenness which she calls "the quarantined deference response." ${ }^{27}$ A practice for discerning when God is appearing and when $\mathrm{He}$ is not is epistemically respectable, and hence respectable for the purposes of baptism by ostension and tradition of a name by testimony, only if it is socially established. Socially established mystical doxastic practices are much narrower, and more tightly controlled, than the whole theistic religious linguistic practice. This narrowness can exclude causal chains gone awry, so that practitioners can "avoid the problem of semantic shift ... by resolving to only defer very selectively when [they] use divine names," ${ }^{28}$ that is, only to successful mystics within their practice.

Unfortunately, Alston's solution makes each community's referent of "God" semantically accessible to "God"-users only at the directly proportional cost of scope for co-reference across those communities. Whatever the object of Ignatius of Loyola's religious experiences, my fellow spiritual

\footnotetext{
${ }^{23}$ Gale, On the Nature and Existence of God, 7, 327-341.

${ }^{24} \mathrm{Gale}$, On the Nature and Existence of God, 47.

${ }^{25}$ Alston, Perceiving God, 184-225.

${ }^{26}$ Alston "Referring to God," 119.

${ }^{27}$ Sullivan, "The Semantic Problem of Divine Hiddenness," 48.

${ }^{28}$ Sullivan, "The Semantic Problem of Divine Hiddenness," 48.
} 
exercisers and I will have secure and easy access to it via "God" by selectively deferring only to St Ignatius's usage of "God." But if we are referring to the same object as other Christians, we must be deferring to earlier and more figures in our quarantine of "God"-users, and semantic hiddenness will return. The situation becomes proportionately worse, God proportionately more "hidden," as we take Jesuit "God"-users to refer to the same object as Jews, Muslims, Zoroastrians, and so on. In other words, advocates of CR must choose a trade-off between reduced scope and reduced accessibility if Gale's objection demands a response like Alston's.

Sullivan's preferred solution to semantic divine hiddenness raises similar difficulties. She argues that the truth of sufficiently robust accounts of providence would imply that the necessary causal chains have in fact been preserved..$^{29}$ St Irenaeus assures us that "the preaching of the Church is on all sides consistent . . . and hath its testimony from the Prophets and Apostles, because the Spirit uses the Church as 'a precious vessel' to guard the 'noble treasure' of the faith." 30 Sullivan notes that this solution ideologically inflates CR to involve divine-providential mechanics as well as familiar causal mechanics. ${ }^{31}$ Other things being equal, then, if Sullivan is right about CR's generation of a problem which demands a theodicy, we should prefer a theory which can remain leaner by not raising the problem at all. A similar consideration will apply to a similar strategy suggested by de Ridder and van Woudenberg: ${ }^{32}$ all humans respond (perhaps in religious experience) to the same God via His general revelation. Particularly, human religions which involve the theistic religious linguistic system use their term translating "God" to pick out the object so responded to. If so, when speakers in different traditions call the object of their religious experiences "God," since it is God indeed who is appearing to them, they will co-refer. It will also "refresh" the causal chains and reduce semantic vulnerability. The doctrine of general revelation may be true, but if an alternative theory of the reference of "God" can do without it, so much the better for that alternative.

One final comment about the scope limitations of CR. CR's advocates typically regard it as a reason to prefer $\mathrm{CR}$ that, thanks to the common

\footnotetext{
${ }^{29}$ Sullivan, "The Semantic Problem of Divine Hiddenness," 49.

${ }^{30}$ Irenaeus, Five Books of S. Irenaeus: Bishop of Lyons, Against Heresies, 302-303.

${ }^{31}$ Sullivan points out that providence is less inflationary than the "reference magnetism" which secular accounts of reference must appeal to in the face of gerrymandered, metaphysically possible beings which match terms' rules of usage just as well as whatever is picked out by baptizing or describing (Sullivan, "The Semantic Problem of Divine Hiddenness," 49). Jumping the gun somewhat, the Worship-Worthiness view appeals to a definite description which excludes gerrymandered rivals to God by allowing users to defer to moral facts to which they might not have cognitive access. The rules of theological discourse are poorly, that is profligately, explained if "God" means some complex definite description which picks out a strange being but yet matches our use of "God," and efficiently explained (I argue) if "God" means "the being which is worthy of our worship."

${ }^{32}$ de Ridder and van Woudenberg, "Referring to, Believing in, and Worshipping the Same God," 60 .
} 
historical origins of the Abrahamic religion, it provides for co-reference between "God"-users of all the Abrahamic faiths. ${ }^{33}$ The considerations I gave to support the scope desideratum might, however, demand a higher bar: apparently genuine theological disagreement occurs across the boundary between the Abrahamic and other faiths - faiths without a common historical origin.

\section{The Descriptive Denotation View}

The simplest version of the Descriptive Denotation view is that "God" refers to Who it does by standing in for a description of someone, and only God satisfies that description. ${ }^{34}$ DD seems a natural way to think about how "God" refers due to the habit of theologians from Arius ${ }^{35}$ to Zizioulas $^{36}$ of "introducing" their readers to God by giving a list of adjectives intended to differentiate Him from everything else. Because the lists of divine names we find in such sources are heterogeneous, presentations of DD need not commit to a specific list as being constitutive of the theory-any more than accounts of CR need to commit to a specific history of the transmission of the name "God."

In terms of general theories of reference, DD could be taken to rely on a Russellian or Millian view about how names "denote" in virtue of their implicit description, along with the understanding that "God" is a name in this sense. Understood in this way, however, DD will be vulnerable to standard objections to this view of names. Instead, DD can be articulated as foregoing the assumption that "God" is a proper name-or even a natural-kind-term - and supposing "God" stands in for a definite description which picks out the set of things which satisfy (perhaps, which could possibly satisfy) that description. If the descriptions involved were too vague, then DD would immediately fare terribly on the scope criterion because co-reference would be threatened by multiple membership of the set of those picked out by "God." Fortunately, however, the candidates for such descriptions which we find in theological literature, liturgy, and the mouths of believers asked to define "God," typically render that set either a singleton or empty. For example, "the creator of the universe" is empty if theism is false, whether because the universe was not created or because it was created by committee. When terms are used to mean things in this way, we sometimes speak of "denoting" as distinct from

\footnotetext{
${ }^{33}$ See Miller, “The Reference of 'God,'” 14; Alston, "Referring to God," 126-127; Sullivan "Semantics for Blasphemy," 162-163 and "The Semantic Problem of Divine Hiddenness," 39, 43 , for agreement on this point.

${ }^{34}$ More refined versions could appeal to "cluster concepts" where not all co-referents need to have the same description in mind, but the descriptions must be part of a set. The refined versions can ameliorate accessibility problems for DD only by expanding the set, reducing the chance that the descriptions in the set in fact pick out one thing, and so increasing scope problems.

${ }^{35}$ As quoted in Athanasius, De Synodis 2:15, 2:16.

${ }^{36}$ See, for example, Zizioulas, Lectures in Christian Dogmatics 40-44.
} 
"referring," and "referring" is then restricted for the kind of "meaning" that names, specifically, have of the things they name. ${ }^{37}$ Since either way we are answering the question of what "thing" or "person" is "picked out" by "God," whether or not "God" operates like a name or a title, I shall continue to write of the "reference" of "God," even if according to this distinction "God" only "denotes" by standing in for a definite description.

DD can be criticized for its threats to accessibility. For any definite description of "God" which plausibly has a unique satisfier, many apparently competent "God"-users will not have that definition in mind. We can address this by supposing, as Alston puts it, that any such user "has in reserve $\mathrm{e}^{\prime 38}$ their denoting description, perhaps mnemonically, but more normally by deference to others. In doing so, we risk re-introducing the ball of tangled deference chains which threatened ordinary believers' accessibility on CR. We can, of course, quarantine our deference to untangle the ball somewhat-but again, it will come at the cost of co-reference with "God"-users at the ends of chains outside our quarantine.

A feature of DD which I find more pressing, however, is that it comes with no normative component as to what definite descriptions are good candidates for definitions of "God." Rather, it implicitly tells us to look at how the theistic religious practice is carried out to devise one. And when we do that, we discover a problem.

DD itself does not specify what definite description allows "God" to denote God. So, just as CR delegates the "true story" about the causal history of the name "God" to intellectual history, DD also delegates the detail of working out the correct definite description. But to what discipline? An answer which has proven attractive to some theologians is "confessional theology." That is, the one who wants to know what "God" denotes might derive a definite description of God from their beliefs about what God is like, more than by considering how the word is used.

When this occurs, it is often part of a wider strategy to close a religious controversy of the typical "I believe that $a$ is F, but you believe $a$ is G" or "We should $\phi a$, not $\psi$ a" forms, and open up a new controversy of the less tractable forms "I believe there's an $x$ which is $\mathrm{F}, a$, but no $x$ which is $\mathrm{G}$, but you believe there's an $x$ which is $\mathrm{G}, b$," and "We should $\phi a$ rather than $\psi$ $b$." The beliefs cited in such manoeuvres are not even always core creedal claims involving concepts widely shared by believers. Consider criticisms of natural and liberal theology at the end of the Reformed tradition: "The God who is "conceived" by thought is not the one who discloses Himself; from this point of view He is an intellectual idol." ${ }^{39}$ By taking the rather odd properties of having-disclosed-Himself-in-the-Incarnation, or

\footnotetext{
${ }^{37}$ This distinction is drawn in Donnellan's argument ("Reference and Definite Descriptions," 281) against Russell's view of the semantics for definite descriptions and, thereby, names.

${ }^{38}$ Alston, "Referring to God," 113.

${ }^{39}$ Brunner, The Christian Doctrine of God, 136.
} 
not-having-been-conceived-by-thought, to be part of a definition for "God," Emil Brunner does not have to show that Reformed Christianity is correct about God and his opponents mistaken. Liberal Protestants and Catholics are just talking about something else, something which is an "idol" as far as Christians should be concerned. Or consider remarks made by Cardinal Burke on Christian and Muslim dialogue in a recent interview: "I don't believe it's true that we're all worshipping the same God, because the God of Islam is a governor." ${ }^{40}$ This absolves him of engaging with the question of who is correct about how God wants humans to live and allows him to re-cast that question into a question about whose being really exists; or-and I think this is telling - whose being is worth trusting for salvation, or obeying, or worshipping.

If this manoeuvre occurred all the time, then it would undermine the empirical claims about theological controversy made in defence of the scope desideratum above. To this reader, however, such manoeuvres stand out as notable exceptions to general practice, exceptions which sometimes seem not to take the religious aspirations of interlocutors as seriously as they deserve. Consider both cases above: Reformed, Catholic, and Lutheran Christians assumed they were disagreeing about the same being for five-hundred years before twentieth-century Protestant criticisms of natural theology. ${ }^{41}$ Christian and Muslim theologians and religious leaders (if not, perhaps, the authors of popular fiction or political propaganda) have almost always regarded each other as disagreeing about the nature of one God.

Since DD delegates the task of spelling out how "God" refers in this way, it risks massively reducing scope for co-reference. The natural solution is to take on that task for ourselves, having reflected on the desiderata of accessibility and scope, and seek to specify a more principled definite description which meets them better. Worship-Worthiness is an attempt at that task. ${ }^{42}$

\footnotetext{
${ }^{40}$ Burke, Wheeler, and Fessio, "Final Transcript-Tele-press Conference with Cardinal Raymond Leo Burke," 17.

${ }^{41}$ See Sudduth's The Reformed Objection to Natural Theology for an overview of this agreement.

${ }^{42}$ This way of jeopardizing scope also affects Causal Reference in a roundabout way which is worth illustrating in response to de Ridder and van Woudenberg's confessional articulation of the Causal Reference view. Consider differing responses to a thought-experiment offered by Alston in his defence of CR:
}

\section{[The Satan Case:]}

Suppose that an impostor-the devil, one's internalized father figure, or whatever-represents himself as God. We are to imagine someone who, like the Old Testament prophets, takes himself to be addressed by God, to be given commissions by God, and so on. But, unlike the Old Testament prophets, as they have traditionally been regarded, our chap is really being addressed by Satan. . . . To make this the kind of case we want we must suppose that this impostor represents himself as the true God, creator of heaven and earth, righteous judge, merciful redeemer, and so on. Thus most of the operative descriptions ... are uniquely true of God, while the direct referential contact is with, say, Satan. . . If it should turn out 


\title{
The Worship-Worthiness View
}

Having considered the Descriptive Denotation view, we can see that the Worship-Worthiness view is a principled iteration of it, rather than a rival on the same level as the Causal Reference view. The Worship-Worthiness

\begin{abstract}
that it was actually Satan, rather than the creator of the heavens and earth, with whom they were in effective contact, would we not have to admit that our religion, including the referential practices involved, is built on sand, or worse (muck, slime), and that we are a Satan-worshipping community, for all our bandying about of descriptions that fit the only true God? (Alston, "Referring to God," 121)
\end{abstract}

Alston finds a positive answer intuitive. Subsequent readers of the case demur. Gale finds that "a wide variety of religious believers . . . all answer Alston's rhetorical question in the negative" (Gale, On the Nature and Existence of God, 301). He is thus persuaded that some form of DD is true and chooses for his uniquely satisfiable description "being a supremely great being ... and being eminently worthy of worship and obedience" (Gale, On the Nature and Existence of God, 8). Jerome Gellman, considering a briefer analogue of the Satan Case ("The Name of God," 541), suggests that communities whose conception of the baptizand is too radically different from its actual nature simply fail to refer-his response implies a disjunctive account whereby even a perfectly intact deference chain is an insufficient condition for successful reference, so worsening accessibility. Jeroen de Ridder and René van Woudenberg take the Satan Case to constitute a counterexample to CR. But rather than adopt DD, they attempt to amend CR in two ways. Their second amendment supposes that reference change occurs for the user of a term if the sense they attach to that term is sufficiently false of the original referent but sufficiently true of another referent (de Ridder and van Woudenberg, "Referring to, Believing in, and Worshipping the Same God," 58). Plausibly, we can identify that kind of reference change with the causal circumstance of a teacher failing to pass on a term correctly. Applied to CR, it will lead back to the semantic vulnerability of "God" so that CR will continue to risk low accessibility.

Their first amendment is that "when someone who baptizes $X$ is mistaken about $X$ in fundamental ways, i.e., about the very kind of thing $X$ is, it is implausible that by baptizing $\mathrm{X}$ she has introduced a referring expression for X into the language" (de Ridder and van Woudenberg, "Referring to, Believing in, and Worshipping the Same God," 58). This amendment immediately invites the question of which mistakes are sufficiently fundamental. De Ridder and van Woudenberg's suggested standard is "the distinctions between personal and non-personal beings, between concrete and abstract entities, between universals and particulars, between substances, properties, stuffs, events, processes, and modifications, and between creator and created" (de Ridder and van Woudenberg, "Referring to, Believing in, and Worshipping the Same God," 64). When this amendment is applied to ascertain whether theistic reference is successful in real-world contexts, it runs into trouble, since

Of particular urgency in relation to the question of coreference among the Abrahamic faiths is the question whether the belief that God is not a Trinity should count as a fundamental mistake that invalidates reference. We confess to having torn intuitions here. On the one hand, whether or not God is a Trinity strikes us as a matter of fundamental ontological category; on the other, it doesn't appear to be quite as fundamental as the distinction between, say, personal and non-personal or between creator and created. Clearly, an answer to the question whether Jews, Christians, and Muslims refer to the same God depends on where you come down on this issue. (de Ridder and van Woudenberg, "Referring to, Believing in, and Worshipping the Same God," 64)

Defenders of the Causal Reference view thus can respond to the Satan Case in two ways. If they treat it as an instance of a semantic shift, the semantic vulnerability of "God" is highlighted and the semantic problem of divine hiddenness demands a theodicy. If they adopt de Ridder's and van Woudenberg's alternative strategy, they must either appeal to their confessional commitments to distinguish more or less "fundamental" properties of God; or, they must appeal to some other standard. The first option is going to narrow scope again. The second option demands the question of what that standard might be. My articulation of the Worship-Worthiness view aims to answer that question in a way which aims to widen scope and increase accessibility. 
view tells us that "God" stands in for the definite description "the being which is worthy of our worship."

Of course, there are alternative iterations of Descriptive Denotation available. The correct iteration could perhaps be "the being which is responsible for the existence of everything else"; or it could be "the being which is capable of saving us"; or "the being which is maximally excellent." To improve the scope, we could substitute vaguer alternatives for these: "the being which is metaphysically ultimate," "the being which is capable of satisfying our ultimate concern," and "the being which is ultimately valuable," respectively. It could be a conjunction of these definite descriptions.$^{43} \mathrm{~A}$ really thorough defense of the Worship-Worthiness view would explain, for each of these possibilities, why it fails to satisfy accessibility and scope to the same degree as WW-in as much detail as was devoted to showing problems with CR and DD more broadly.

Instead, however, I suggest that there is a generic issue with these alternatives, which WW turns out to be free from. The first is that the name the definite description "God" stands in for must be possibly satisfied by only one being, otherwise the reference of "God" in the mouths of different speakers will split too easily. There could in principle be multiple creators or multiple saviours. Independently of the considerations I raise below, which emerge out of thinking about the nature of worship, there could perhaps even be multiple beings who are maximally excellent.

Now, as they are written above, any of these alternatives could include a stipulative component to ensure that they are definite descriptions which rigidly designate-a "uniquely" element as in "the being which is uniquely responsible for the existence of everything else," "uniquely capable of saving us," and so on. But insofar as they carry such stipulative components these alternatives will be less accessible. "God"-users can competently refer even with very limited and inchoate conceptual resources. The burden of proof will fall on the advocate of any iteration of DD which includes a stipulative component, to show that all these "God"users have implicit access to the "artificial" concept resulting from the stipulation. Below I will argue that the concept and norms of worship, however, are learnt through ordinary social interaction from a young age: the kinds of cosmological, ontological, and axiological concepts involved in these alternative iterations of DD do not have this advantage.

So, to avoid simply stipulating that God is "the being which is uniquely worthy of our worship," and so make sure pretty much all "God"-users have easy access to the concept which picks out God, we need an argument that our intuitive understanding of worship suggests only one being can be worthy of worship. The argument I offer below follows recent analyses of worship which suggest that worship, considered as an attitude, is

\footnotetext{
${ }^{43}$ Schellenberg's "ultimism" is the view that the object of religious engagement is best understood, for reasons of epistemic humility, as whatever meets (if anything does) such a conjunct definite description. For a brief prospectus of Schellenberg's ultimism see his "God For All Time."
} 
a special case of praise and that desert of both worship and praise tracks the excellence of the object of worship. For the sake of concision, I accept both of these claims in what follows-but it is worth pointing out that if anything is objectively worthy of worship, there is at least one property which worthiness of worship tracks. So, an alternative argument to the one below should remain viable on alternative sets of properties and associated attitudes used to analyze worship.

In their discussion of the phenomenology of worship, Tim Bayne and Yujin Nagasawa present what they call the "uniqueness thesis": that only one thing, God, is worthy of worship. ${ }^{44}$ They suggest that the acceptance of the uniqueness thesis is what sets monotheism apart from polytheism: in the terms of this debate, they are claiming that the theistic religious linguistic practice definitely involves it, but polytheistic practices might not. Plausibly, however, all religious linguistic practices which include the term "God" "with a capital "G," alongside the term "god" for other entities their religions involve, set the referent of "God" apart from and above those gods in some way. The distinction between worship and "mere praise," or between worship and "veneration and hero-worship," or worship and "instances of worship which should be subservient," 45 tracks the distinction between "God" and the gods. So, there is a narrower and intuitive sense of "worship," to which uniqueness seems to apply, at play in all contexts where religious language involves the term "God" and not merely "god."

Bayne and Nagasawa take aim at monotheism for being unable to articulate the difference in kind between the attitude owed only to God according to the uniqueness thesis and the attitudes we take to our creaturely heroes. ${ }^{46}$ Jeremy Gwiazda's response is to identify "worship" with the degree of praise owed to the most praiseworthy and to identify praiseworthiness with excellence ${ }^{47}$ At this level of simplicity, Gwiazda's account seems to fit well with the data of monotheistic and henotheistic religions - that is, all the religions which use the theistic religious practice. On it, any maximally excellent being will be worthy of worship. In order to secure uniqueness, however, Gwiazda gives a strong account of maximal excellence according to which only the best possible being can count, and uniquely so, since that maximal excellence entails His transcendence. ${ }^{48}$

That Gwiazda appeals to controversial claims about the structure of value, in order to guarantee that only one being is worthy of worship, does not mean that these claims must be true in order for the uniqueness thesis to be true about the nature of worship; nor does it mean that these claims must be true, or be believed or understood by "God"-users, in order for those speakers to successfully refer to God by implicitly understanding

\footnotetext{
${ }^{44}$ Bayne and Nagasawa, "The Grounds of Worship," 301.

${ }^{45}$ Bayne and Nagasawa, "The Grounds of Worship," 302.

${ }^{46}$ Bayne and Nagasawa, "The Grounds of Worship," 302.

${ }^{47}$ See Gwiazda, "Worship and Threshold Obligations."

${ }^{48}$ Gwiazda, "Worship and Threshold Obligations," 523.
} 
"God" to mean "the being which is worthy of worship." Just as long as uniqueness is in fact true of the nature of worship, and God is in fact (for whatever reason) solely worthy of worship, then He will be the only thing picked out by "God." The uniqueness thesis and the notion of worship which involves it is phenomenologically independent from the axiological claims Gwiazda uses to defend its coherence.

I suggest we follow Bayne and Nagasawa in taking the uniqueness thesis as data from the phenomenology of religion. And according to it, if it turns out that if anyone is worthy of worship, then the set of actually existing maximally excellent beings is a singleton. If there are multiple beings who are equally best, then no-one is referred to by "God." If no-one is actually the uniquely best then no-one is worthy of our worship, and "God" does not refer, except in the fictional or conditional sense discussed in the introduction. For now, let's take the uniqueness thesis to be true so that we can easily see how well WW fares against our desiderata. Later, I will return to defend it more thoroughly.

One more assumption must be taken as data from the phenomenology of worship: that although being the best is necessary for being worthy of worship, it is not sufficient. One must also surpass an absolute threshold of excellence. Otherwise, WW is subject to a range of counterexamples in which "God" refers to pitiful or evil beings just in virtue of their being the least pitiful or evil who actually exist. As with the relative excellence condition defended above, this condition on worthiness of worship can be defended with more substantive accounts of worship or excellence, but WW need only commit to the condition, not to any particular reasons for imposing it. I take the obvious absurdity involved in worshipping the least-evil (or least-pitiful) being available to show that this latter condition needs less defense than the uniqueness thesis.

The practices of praise-giving, or whatever other attitudes worship might be a limit case of, such as awe or gratitude, are socially endemic and learnt young. Analogues of worship can be present and proper in local, restricted domains even if only God deserves worship "proper" in a global or unrestricted domain. It makes sense to speak of my worshipping my older brother qua the most excellent older boy at school, and we can at least make sense of our daughters' worship of Justin Bieber qua most talented of pop-stars. Indeed, our disagreement with their judgment will initially have to do with Bieber's talents as a pop-star, not with Bieber's inferiority to Yahweh. If this is true, then there is evidence that we are fast learners not only when it comes to praise, awe, and gratitude but, also, about the distinction between their common, and their limit, cases of desert.

These examples allow us to flesh out the uniqueness thesis a little more:49 it tells us that worship belongs only to the best within a given domain

\footnotetext{
${ }^{49}$ This is a somewhat formal way of expressing Bayne and Nagasawa's observance that in some contexts the word "worship" is used in ways that imply multiple objects can be worthy of worship. They give two examples: the veneration of saints and fraternal adoration of a younger for an older brother, as I have used. In discussing the role uniqueness plays in
} 
of comparison. But we can of course conceive of a global domain, of all candidates that could possibly be measured for excellence. Then it can come out true, all together, that Bieber is in a local sense "worthy" of the "worship" children offer to pop-stars, while older siblings are "worthy" of the "worship" they offer to older children, while nevertheless only God is worthy of worship simpliciter, and it would be improper to worship Bieber or one's older sibling in that global domain.

I suggest that "the being which is worthy of our worship" in the global, absolute sense of "worship," is implicitly understood to define "God" by the term's speakers, even if they would not respond to a question about what "God" means by giving WW's definition.

In this way, the Worship-Worthiness view renders God extremely semantically accessible in terms of both conceptual demands and semantic vulnerability. Because the concept of worship comes so easily to us through induction into analogous social practices, hardly any "God"-users will fail to meet the conceptual demands required to successfully denote God with the term. Because the speaker only needs to use the term with an implicit associated sense, no history of causal connections to baptizers is required. So WW thereby renders God highly semantically accessible by rendering "God" semantically invulnerable, relative to its vulnerability on the Causal Reference view.

The Worship-Worthiness view also does well in determining wide co-reference because it implies that co-reference will cut across religions' different histories, no matter how complex, diverse, or divergent they are. It will also cut across religions' differing metaphysical conceptions of God-perhaps not as unilaterally as their histories, but significantly more so than on CR or DD. It might be thought that the Worship-Worthiness view determines that God must be personal and so splits reference between those who accept God's having a mental life and those who reject it or believe claims about God which might be taken to exclude it. On the other hand, religions which use the theistic linguistic practice, but involve theological claims in tension with God's personhood, nevertheless involve personal language or imagery whenever worship is actually taking place: when worshipping ipsum esse subsistens, Christians address God as "Father" and "Jesus"; when engaging in worship of Brahman, Hindus venerate images. Perhaps this indicates that non-personal objects can be worthy of worship, or perhaps it indicates that anti-personal claims about God's nature need to be interpreted rather cautiously.

\section{Defending the Uniqueness Thesis}

I have argued that the signal advantage of the Worship-Worthiness view over other iterations of Descriptive Denotation is that it can guarantee

theists' norms of worship, they argue that the theistic linguistic practice privileges worship in the global sense above these other analogical or local instances (Bayne and Nagasawa, "The Grounds of Worship," 302). 
wide co-reference without requiring "God"-users to bear in mind a concept which requires an additional stipulation to prevent reference from splitting. This advantage depends on the uniqueness thesis's being true, and true of a concept of worship to which the typical "God"-user gets "easy" access through their social induction into widespread habits and norms.

But is the uniqueness thesis true? For Gwiazda, the uniqueness thesis comes out true of all worship only thanks to controversial claims about the structure of value: only the greatest possible being is worthy of the most praise, and only one being can be the greatest possible. Bayne and Nagasawa initially present the uniqueness thesis as a thesis about the norms of worship which theists do or perhaps should endorse, ${ }^{50}$ while elsewhere appealing to it to discredit praise-based accounts of worship as though it were intrinsic to worship rather than a theistic postulate..$^{51}$ So it is ambiguous whether they endorse it. Swinburne's concise presentation of a praise- and gratitude-based justification for worship, however, gives us one example where it is implicitly rejected: "The first religious reason for following a religious way is to render proper worship and obedience to whatever God or gods there are" (my italics). ${ }^{52}$ Following Swinburne, I have argued elsewhere that the uniqueness thesis is not a norm of worship as such, but a norm of worship only given theism..$^{53}$ So the uniqueness thesis is at least controversial.

Consider the following case:

The Brothers Case:

A wanderer in the desert enjoys a religious experience which impresses upon him that its object, which he dubs Jim, is incomparably more excellent than anything else the wanderer has ever come across. It seems to the wanderer that the being must be utterly unique in its excellence. Before the object of his experience tells him the following, he is struck by an attitude of utmost praise.

\footnotetext{
${ }^{50}$ Bayne and Nagasawa, "The Grounds of Worship," 302.

${ }^{51}$ Bayne and Nagasawa, "The Grounds of Worship," 308. Their argument is that if worship is a special case of some other attitude, and God were worthy of our worship because $\mathrm{He}$ is worthy of that other attitude, but creatures are also sometimes worthy of that attitude, then those creatures would also be worthy of worship. But since uniqueness is true, those creatures cannot be worthy of our worship; so neither can God. Bayne and Nagasawa suppose that it would be unacceptable to theists to respond by recognizing an analogical usage of the term "worship," properly used of creatures when they are worthy of great degrees of praise, gratitude, awe, or whatever else (Bayne and Nagasawa, "The Grounds of Worship," 302). The response offered by Gwiazda, which I have followed here, is that the limit case of maximal excellence can occupy the right side of a threshold that triggers an obligation to respond with worship, whereas mere praise or veneration are the proper response to beings on the other side (Gwiazda, "Worship and Threshold Obligations," 522).

${ }^{52}$ Swinburne, Faith and Reason, 168.

${ }^{53}$ Burling, “Do We Owe God Worship?" 3-4.
} 
Then, the object of his experience speaks, and informs the wanderer that it is one of a pair of such beings. The wanderer mentally dubs the other Tim. ${ }^{54}$

If worship is the attitude we should take to the most excellent, then it seems that, at least subjectively speaking, the wanderer ought to worship Jim before Jim informs him about Tim. But uniqueness seems to imply that, after Jim informs the wanderer about Tim, the wanderer should worship neither of them.

On the one hand, this implication seems no more intuitive than responses inconsistent with uniqueness. Perhaps, after Jim speaks, we are obliged to split our praise-giving activities and attitudes equally between the two; or perhaps we are obliged to worship just one, but entitled to choose between them. On the other hand, perhaps we can distinguish between a conception of worship on which uniqueness is true, and one on which it is not. According to the former the wanderer loses his subjective obligation to worship Jim the moment he learns about Tim, but according to the latter it is still obligatory or appropriate for him to worship both - or perhaps even whichever he chooses. ${ }^{55}$ What the Worship-Worthiness view needs is for the former conception to reflect a moral practice to which we have easy access through socialization into praise-giving practices. Then WW can be built on that practice, even if there is another nearby alternative we might also call "worship," which does not include uniqueness.

Perhaps another angle from which we might see the role uniqueness plays in worship is that of the wrongness of idolatry, understood as worshipping the wrong object, rather than worshipping a physical rather than personal object. Perhaps idolatry is wrong because it betrays a serious, exclusive commitment that a worshipper has made to her object of worship. Although this interpretation receives support from within the Jewish and Christian traditions, whose scriptures maintain a strong thematic connection between idolatry and adultery, this support is not conclusive for us: our target is a notion of worship not restricted to any tradition.

It may be instead that the wrongness of idolatry is explained in terms of the uniqueness thesis, and the connection between idolatry and infidelity

${ }^{54}$ Thanks to an anonymous reviewer for contributing this counterexample to the uniqueness thesis. Bayne and Nagasawa consider a more abstract version of it (Bayne and Nagasawa, "The Grounds of Worship," 308) to attack praise-based accounts for violating the uniqueness thesis by taking the example to obviously imply that we would be obliged to worship both beings and they to worship each other.

${ }^{55} \mathrm{An}$ anonymous reviewer points out that the issue represented by the Brothers Case may also be presented by the doctrine of the Trinity. The uniqueness thesis renders Christianity polytheistic, if polytheists are those who (idolatrously, according to the thesis) worship multiple beings. It is possible to interpret passages such as Philippians 2:11 and Revelation 4 and 5 as implying that the Father and Son are two distinct objects of worship; presumably, it is also possible to independently articulate trinitarianism so as to produce the same result. The trinitarian defender of the uniqueness thesis should insist that even if these interpretations and articulations do indeed result in polytheism, all this shows is that we must affirm the Father's and Son's consubstantiality in order to render them the same object of worship. 
to an exclusive, explicit commitment is merely a natural one to make, rather than idolatry being a special instance of infidelity. The most straightforward way to show that the wrongness of idolatry is grounded in uniqueness, rather than fidelity to an exclusive commitment, is to give a case where it seems right to break off a commitment to worshipping one person, in order to worship another, in spite of such a commitment being in place.

\section{The Trade-Up Case:}

Tamm is a prophet of Baal, a very impressive being. Tamm leads his household and groups of his countrymen in worshipping Baal, who is the most excellent being of which Tamm is aware. Baal is not only a very powerful lightning-manipulator, but is involved in carefully sustaining the human race by supervising his family in managing weather and fertility.

One day, however, Tamm is summoned along with his colleagues to watch Elijah, a prophet of a rival deity, Yahweh, carry out a demonstration to show that Yahweh is more powerful than Baal. The supernatural events at the demonstration give Tamm sufficient evidence to believe that Yahweh is more powerful than Baal; but they also persuade Tamm to take Elijah's theological claims seriously. Elijah explains that Baal does not enjoy sole providential control over nature, but that Yahweh, whom Tamm had previously believed to have handed over authority to Baal millennia ago, is not only the creator but also continues to exercise providential care over humans and animals.

Before the demonstration, Baal is worthy of Tamm's worship, at least subjectively speaking, given Tamm's information. If we don't think Baal's attributes as described above put him above the absolute threshold of excellence required for worthiness of worship, we can stipulate additional details in the first part of the Trade-Up Case to satisfy that condition.

It seems that after the demonstration Tamm would be praise-worthy, rather than blame-worthy, for transferring his worship over to Yahweh given his new epistemic situation -in spite of breaking his standing commitment to worship Baal. At any rate, we are unlikely to accuse Tamm of committing idolatry by changing his loyalties. Rather, we might accuse him of idolatry for continuing to worship Baal instead of or alongside Yahweh, given what he now knows.

So far, however, our response to Trade-Up only shows that the wrong of idolatry is not reducible to the wrong of infidelity. To support the view that the wrongness of idolatry implies the uniqueness thesis we need a case where we judge someone as guilty of idolatry for changing or dividing their loyalties between equally-good deities, pace Swinburne's view that worship could be owed to multiple deities at once.

The Trade-In Case:

Tamm is a prophet of Baal, a very impressive being. Tamm leads his household and groups of his countrymen in worshipping Baal, who 
is the most excellent being of which Tamm is aware. Baal is not only a very powerful lightning-manipulator, but is involved in carefully sustaining the human race by supervising his relations in managing weather and fertility.

One day, however, a priest arrives in Tamm's land from the distant northwest. This priest worships Zeus and performs impressive ceremonies and recites beautiful poetry so that Tamm can see that the priest is a reliable source of information about Zeus. Zeus is, by the priest's account, an equally powerful lightning-manipulator and also involved in carefully sustaining the human race by supervising his (albeit less co-operative) family in managing weather and fertility. All told, Zeus is just exactly as excellent as Baal.

For Tamm to now worship Zeus instead of Baal seems like a paradigmatic act of idolatry. ${ }^{56}$ This would remain the case if he simply incorporated the worship of Zeus into the religious life of his family and "congregation," alongside Baal. Note that we are not considering his syncretizing Baal and

${ }^{56}$ These cases are built from an anonymous reviewers' observations about ambiguities in the norms of worship described in the Old and New Testaments. They point out that, in religious-political contexts as they are described in the Old Testament we have nations worshipping their own deities or pantheons, while aware of each others' deities and pantheons, and each others' religious practices. So perhaps our intuitions in response to the fictional Trade-In run counter to the actual worship-practices of historical polytheistic religions. There are three ways of defending uniqueness from this actuality. Firstly, the Old Testament record may obscure how each nation really perceived the deities of other nations: they may have regarded them as inferior, and hence were in a situation more like Tamm's before encountering Elijah or the priest of Zeus. They may have thought there would be some value in changing who foreigners worshipped, but not prioritised doing so; the Old Testament implies they made some effort since Israelite kings apparently found their proselytising convincing. Secondly, these uniqueness-violating practices may have been wrong, and our intuitions in response to the Trade-Up and Trade-In case reveal this. Then Jews and Christians can interpret Yahweh's interactions with Israel and her rivals and conquerors as helping correct humanity's worship practices in a time and place where, for whatever social or political reason, they had become deficient. Thirdly, we can judge these uniqueness-free worship-practices of pagan polytheists as described in the Old Testament as in some sense a "legitimate" moral practice which is nearby to the one WW calls "worship," and can sit alongside it; then WW will survive as long as WW's "worship" is commonplace enough in social practices.

A corollary of this reviewer's interpretation of Ancient Near-Eastern polytheism (or at least the plausible construction narrated in parts of the Old Testament) is that, to the extent that the Old Testament presents Yahweh as another deity who is distinguished from rivals only by his covenant with Israel and his having created the world, Old Testament theology will not really be theistic according to WW; and the religious linguistic practice of the Israelites as presented there will not be an appropriate one to analyse to give an account of the reference of "God."

This might imply that these polytheistic Israelites failed to refer to God: they refer only to the fictional character, or tribal deity, Yahweh. By lacking the correct concept of worship, they do not have the conceptual apparatus to succeed in referring to God by terms such as "El" or "Adonai" according to WW. But, of course, if Yahweh is interacting with them, they can refer to Him in the standard causal way using any terms which function as proper names, rather than using them in the titular way WW supposes "God" works. If Yahweh is God, then they can refer to God using these proper names. (If Yahweh is not God, they cannot.) As their theology drifts towards being more properly heno- or mono-theistic through obedience to the Law, they will enter into the theistic religious linguistic practice, acquire the necessary conceptual apparatus, and then use these proper names as Hebrew for "God." 
Zeus, in which case he would continue to worship only one being and continue to worship Baal. If Tamm would be guilty of idolatry for worshipping Zeus, even though Zeus is just as good as Baal, and if "worthy of" is the mirror of "owed to," then Tamm's owing worship to exactly one deity establishes that exactly one person can be worthy of worship in a given domain of excellence. The alternative explanation is that Tamm would be guilty merely of a kind of infidelity to Baal, but Trade-Up excludes such an interpretation. Furthermore, I suggest that once Tamm knows about Zeus, he would be unable to approach Baal and lead acts of worship toward him in the same good faith as before since he will now see Baal as fungible. In a third case where Tamm accesses all the information he has across both Trade-Up and Trade-In, we would conclude that he should give up worshipping Baal or Zeus for Yahweh.

Trade-Up and Trade-In together show us that the norms of worship are stranger than we might initially have noticed. The remaining danger for the Worship-Worthiness view is that if we secure the uniqueness thesis only by drawing attention to the strangeness of worship norms, we have cut it off from the easily-accessed, routinely socially learnt, moral habits which made the referent of "God" so accessible. When explaining the connection between "religious" worship and its "everyday" analogues above, I gave the example of worshipping a sibling qua best older boy in one's school, and worshipping a pop star qua best among the pop-stars. One way of showing that the conception of worship which includes uniqueness is easily learnt would be to re-run analogues of Brothers, Trade-Up, and Trade-In involving school heroes and pop-stars. A difficulty with this strategy might be that readers not inclined to hero-worship or fandom might apply a nearby concept of praise-giving which often answers to "worship" in English, but is distinct from the "worship" used by the Worship-Worthiness view. The same will arise for other human analogues to these cases. ${ }^{57}$ Hopefully, however, these readers will recognize the plausibility of interpreting creaturely re-runs of these cases in a way favourable to uniqueness. If so, they must acknowledge that many others are in possession of the conceptual and practical framework which involves uniqueness and is required by WW.

An additional strategy is to cast our net wider than praise-giving to other ordinary attitudes, governed by readily learnt moral norms, which involve something like uniqueness, and see whether they could "teach" the "God"-user the normative practice and concept they need for successful reference. Here is one suggestion: Scruton argues that the wrongness of

\footnotetext{
${ }^{57}$ For clarity's sake, here is such an example: perhaps my younger daughter tells me she "worships Justin Bieber," and I can tell from talking to her about what she means, that this kind of praise disdains all others - she won't even take Harry Styles's name upon her lips. But my elder daughter insists she worships Harry Styles and Zayn Malik equally. The Worship-Worthiness view does not need to insist that my eldest daughter is mistaken; it only needs us to be able to recognize that her attitude and practice is different from her sister's and that her sister's attitude and practise is a common one.
} 
idolatry is explained by its being "the peculiarity of sacred things, that they do not admit of substitutes.... The object of worship is to be placed apart, in the world but not of it, to be addressed as the unique thing that it is." He claims that this un-substitutability is "what we mean by calling it sacred." ${ }^{58}$ Importantly, the notion of sanctity at play here is one that, Scruton points out, extends over different domains outside of worship. He uses it to explain our treatment of corpses, which represent the deceased individuals who are non-fungible to the bereaved, ${ }^{59}$ and also the way in which pornography profanes the human by making what we should see as a non-fungible person, fungible with any other body. ${ }^{60}$

Scruton argues that the interest in something just as that individual, and not as a member of its kind or as something to use to bring about a state of affairs, is a completely routine phenomenon in our intentional lives: it is the intentional attitude we take toward any object of aesthetic interest, not just humans as beloved persons. ${ }^{61}$ In the aesthetic case this attitude leads us to want to contemplate or admire the object. I see no reason, however, why along with our praise-giving practices directed at agents our practices of contemplation or admiration directed at objects of aesthetic interests should not also play their role in equipping many of us with the notion of worship at stake here, one governed by something like the uniqueness thesis. Certainly, this notion of worship is closer at hand to more "God"-users than the theological concepts required by rival iterations of Descriptive Denotation and is not vulnerable to the eddies of intellectual history like the causal chains involved in the Causal Reference view.

\section{Two Kinds of Counterexample}

There are two sources of powerful prospective counterexamples to the Worship-Worthiness view. The first is that the view seems to distribute modality across claims about God in counter-intuitive ways. For example, if "the being that is worthy of our worship" is a description for which "God" implicitly stands in, then it will be analytically false that "God is not worthy of our worship." And this might not seem analytically false: many logically competent people seem to have been brought to believe it by experiences of suffering for which they took God to be responsible. Here is how we should handle such cases. In analogous linguistic practices involving titles, which refer by picking out a singleton set bounded by a description, like "King," "Champion," and so on, the semantic reference

\footnotetext{
${ }^{58}$ Scruton, Beauty, 179-180. It could be objected that the Trade-Up Case implies that objects of worship can in fact be substituted, since anything else which is the best in the domain will "do just as well." The idolatry involved in exchanging Baal for Zeus in Trade-In, however, shows things are not that simple. When Tamm trades up to Yahweh he is not substituting a proper object of worship for an equally adequate replacement; rather, he is realising that Baal is not a proper object of worship.

${ }^{59}$ Scruton, Beauty, 177.

${ }^{60}$ Scruton, Beauty, 162-166.

${ }^{61}$ Scruton, Beauty, 19-20.
} 
determined by the description can come apart from the speaker's reference. Such practices can involve local usages with messy relationships to the global semantics, in which the title comes to be treated as a proper name in the Kripkean, causal manner. ${ }^{62}$ So I could come to treat "God" as if it were a proper name for Yahweh rather than a title I take Yahweh to bear. Then, when I suffer at Yahweh's hands, I can coherently (but, if Yahweh is God, falsely) believe that "God is not worthy of our worship." "God" can be unworthy of our worship only in the sense that "the Champion" can be the loser of the tournament.

The second kind of counter-examples I will consider are those where beliefs about the nature and activities of God differ so widely that we might think that a "God"-user, upon changing their beliefs, comes to view their previous beliefs as pertaining to an entity they now regard as fictional..$^{63}$ They might now think that they had previously failed to refer. But on WW, they would be mistaken: they were referring to the being worthy of our worship all along, if It exists. The critic of the Worship-Worthiness view can argue that WW is mistaken because the beliefs of these characters about their own referential success or failure are better evidence than the considerations in favour of WW. This objection presumes that practitioners know their own practices' rules better than those practices' commentators.

Such cases would not function against counterexamples to vague definite descriptions with a unique satisfier in non-theological contexts, however-in those other contexts, we simply accept that people can easily be mistaken about whether or not they successfully referred or what they really referred to. Consider the infamous Jack the Ripper. "Jack the Ripper," at least according to Kripke, ${ }^{64}$ had its reference fixed by a definite description something like "the being which committed all the Whitechapel murders." If the Whitechapel murders were perpetrated by a team of copycats, "Jack the Ripper" failed to refer to any of them. Suppose in that world our detective discovers the truth: he will realize that he had been referring to a fictional character all along. But if the Whitechapel murders were perpetrated by one man, then the detective is referring to that man. And he will have been referring to that man even if he erroneously comes to believe that the murders were committed by a team of copycats. This detective is like our Christian who converts to, let's say, neo-pagan polytheism. After her conversion, she believes she failed to refer to God since (she believes) there is no being worthy of her worship. But if God exists, she successfully referred to God whatever she believes about God's fictional status before her apostasy. Because people can so

\footnotetext{
${ }^{62}$ See Donnellan's case of the usurper whom both loyalists and traitors call "the King" despite both sides knowing he is a usurper ("Reference and Definite Descriptions," 290-291).

${ }^{63}$ Thanks to an anonymous reviewer of a previous draft of this article for offering counter-examples of this kind.

${ }^{64}$ For Kripke's analysis of the Jack the Ripper case see Kripke, Naming and Necessity, 79, 94.
} 
easily be mistaken about the success (or direction) of their reference, the attitudes of characters in these cases about their own referential success are not a good reason to reject the Worship-Worthiness view.

\section{Conclusion}

The Worship-Worthiness view, which defines "God" as "the being which is worthy of our worship," dominates in competition the rivals that we have considered. Causal theories of reference, applied to God, struggle to ensure that reference is available to all the users of the term who appear perfectly capable of using it; when these theories are refined so as to introduce less semantic vulnerability, they struggle to permit co-reference between people who appear to be referring to the same thing when they discuss God with each other, or speak to Him alone, or in concert. An unprincipled descriptivist alternative risks restricting successful reference to a small minority of those who speak of and speak to "God"; and it cannot explain the way in which co-reference is assumed by parties to theological controversies who have fundamentally different beliefs about God. The Worship-Worthiness view, on the other hand, provides for an account of what unites religions whose practitioners speak of and to what they call "God" and gives a simple account of how it is they are so routinely successful in doing so. If there are strong moral motivations for worship, ${ }^{65}$ it also helps to explain the perennial importance of theology and religious behaviour. $^{66}$

Uppingham School

\section{References}

Alston, William P. 1988. "Referring to God." International Journal for Philosophy of Religion 24: 113-128. https://doi.org/10.1007/BF00138720

Alston, William P. 1991. Perceiving God (Cornell University Press).

Alston, William P. 1993. "Aquinas on Theological Predication: A Look Backward and a Look Forward." In Reasoned Faith: Essays in Philosophical Theology in Honor of Norman Kretzmann, edited by Eleonore Stump (Cornell University Press), 145-178.

Aquinas, Thomas. 1964. Summa Theologiae. Translated by Herbert McCabe (Eyre \& Spottiswoode).

\footnotetext{
${ }^{65}$ Burling, “Do We Owe God Worship?" 13-14.

${ }^{66}$ The first draft of this article was presented to Notre Dame's Center for Philosophy of Religion weekly workshop during my visiting fellowship there, and I would like to thank the committee and the John Templeton Foundation for making that possible. I'd also like to thank the participants and my colleagues in the Center for their comments and feedback. For reading and commenting on that and subsequent drafts, I'd like to thank Chris Menzel, Lorraine Keller, Douglas Hedley, and various anonymous reviewers.
} 
Athanasius. 1892. "De Synodis." Translated by John Henry Newman and Archibald Robertson. In Nicene and Post-Nicene Fathers, Second Series 4, edited by Philip Schaff and Henry Wallace (Christian Literature Publishing Company). Accessed at Nov. 30, 2016, at www.newadvent.org/fathers/2817.htm.

Bayne, Timothy, and Yujin Nagasawa. 2006. "The Grounds of Worship." Religious Studies 42: 299-313. https://doi.org/10.1017/S0034412506008420

Bogardus, Tomas, and Mallorie Urban. 2017. "How to Tell Whether Christians and Muslims Worship the Same God." Faith and Philosophy 34: 176-200. https://doi.org/10.5840/faithphil201741178

Brunner, Emil. 1950. The Christian Doctrine of God. Translated by O. Wyatt (Westminster Press).

Burling, Hugh. 2018. “Do We Owe God Worship.” Religious Studies Firstview Articles: 1-16. https://doi.org/10.1017/S0034412518000136

Burke, Raymond, Lisa Wheeler, and Joseph Fessio. 2016. "Final Transcript-Telepress Conference with Cardinal Raymond Leo Burke." Accessed on June 11, 2019, at https://drive.google.com/file/d/0B5FGuFFkfrDvOHBrYWhMcHZ1SWc/ view.

de Ridder, Jeroen, and Rene van Woudenberg. 2014. "Referring to, Believing in, and Worshipping the Same God: A Reformed View." Faith and Philosophy 31: 46-67. https://doi.org/10.5840/faithphil20141104

Donnellan, Keith S. 1966. "Reference and Definite Descriptions." The Philosophical Review 75: 281-304. https://doi.org/10.2307/2183143

Egbo, Edmund. 1972. "A Reassessment of the Concept of Ibo Traditional Religion." Numen 19: 68-79. https://doi.org/10.1163/156852772X00052

Gale, Richard. 1991. On the Nature and Existence of God (Cambridge University Press).

Geach, Peter. 1969. God and the Soul (Routledge and Keegan Paul).

Gellman, Jerome I. 1995. "The Name of God." Nous 29: 536-543. https://doi.org/10.2307/2216286

Gwiazda, Jeremy. 2011. “Worship and Threshold Obligations.” Religious Studies 47: 521-525. https://doi.org/10.1017/S0034412510000508

Hick, John. 1989. An Interpretation of Religion (MacMillan). https://doi.org/10.1057/9780230371286

Irenaeus. 1872. Five Books of S. Irenaeus: Bishop of Lyons, Against Heresies. Translated by John Keble (Parker \& Co).

Kripke, Saul. 1980. Naming and Necessity (Harvard University Press).

Miller, Richard B. 1986. "The Reference of 'God.'” Faith and Philosophy 3: 3-15. https://doi.org/10.5840/faithphil1986313

Schellenberg, J. L. 2016. "God for All Time: From Theism to Ultimism." In Alternative Concepts of God, edited by A. Buckareff and Y. Nagasawa (Oxford University Press), 164-177. https://doi.org/10.1093/acprof:oso/9780198722250.003.0010

Scruton, Roger. 2009. Beauty (Oxford University Press). https://doi.org/10.1093/actrade/9780199229758.001.0001

Sudduth, Michael. 2009. The Reformed Objection to Natural Theology (Ashgate). https://doi.org/10.24204/ejpr.v1i2.340 
Sullivan, Meghan. 2012. "Semantics for Blasphemy." Oxford Studies in Philosophy of Religion 10: 173-201. https://doi.org/10.1093/acprof:oso/9780199656417.003.0009

Sullivan, Meghan. 2015. “The Semantic Problem of Divine Hiddenness." In Hidden Divinity and Religious Belief, edited by A. Green and E. Stump (Cambridge University Press), 35-52. https://doi.org/10.1017/CBO9781139939621.003

Swinburne, Richard. 2005. Faith and Reason (Clarendon). https://doi.org/10.1093/acprof:oso/9780199283927.001.0001

Tilley, Terrence. 1994. "Religious Pluralism as a Problem for 'Practical' Religious Epistemology." Religious Studies 30: 161-169. https://doi.org/10.1017/S0034412500001451

Tuggy, Dale. 2016. “The 'Same God' Controversy and Christian CommitmentPart 1." Accessed on August 13, 2018, at http://trinities.org/blog/the-same-godcontroversy-and-christian-committment/.

Zizioulas, John. 2008. Lectures in Christian Dogmatics. Edited by D. Knight (T\&T Clark). 